The Dynamics of Rules 



\section{The Dynamics of Rules}

Change in Written Organizational Codes

JAMES G MARCH

MARTIN SCHULZ

XUEGUANG ZHOU

STANFORD UNIVERSITY PRESS

STANFORD, CALIFORNIA 
Stanford University Press

Stanford, California

(C) 2000 by the Board of Trustees of the Leland Stanford Junior University

Printed in the United States of America CIP data appear at the end of the book 